The Philosophical Journal of Conflict and Violence

Vol. II, Issue 2/2018

(C) The Authors 2018

Available online at http://trivent-publishing.eu/

\title{
Violence in North-American Indian Sports Games
}

\author{
Fabrice Delsahut
}

ESPE University Paris Sorbonne / L-Vis Lyon 1, France

\begin{abstract}
North American Indians have often been perceived as violent, bloodthirsty buman beings. The horrified fascination exerted by this violence on the European imagination takes hold of all historical accounts and lies at the heart of the smallest social productions. The sports games, whose imposing corpus is intriguing to the colonists, are also perceived as a cultural element of this gratuitous violence, a biological one, even, as inherent to their "wild nature". And yet, far from being instinctual, this violence takes on a ritual and propitiatory dimension that is at the same time at the service of private interests, but also, and especially so, of tribal ones.

By taking possession of the lacrosse game through its institutionalization, Canadians hope to control the violence of this emblematic game-ritual. Despite a deep transformation of the game, the instinctual manifestations in the human relationships that are supposed to decline through the internalization of restrictions subsist. The original game still seems to express itself through this violence-based relationship, no matter how codified.

Drawing on archives ranging from missiological writings to anthropological documents, as well as on recent academic studies, this article tries to dispel the defining halo of a violence sometimes confused with distinct forms of aggressivity.
\end{abstract}

Keywords: Anthropology; Games; Lacrosse; North-American Indians; Rituals; Sports; Violence.

\section{TRIVENT}

The PJCV Journal is published by Trivent Publishing.

This is an Open Access article distributed in accordance with the Creative Commons Attribution Non Commercial (CC-BY-NC-ND 4.0) license, which permits others to copy or share the article, provided original work is properly cited and that this is not done for commercial purposes. Users may not remix, transform, or build upon the material and may not distribute the modified material (http:/ / creativecommons.org/ licenses/ by-nc/4.0/) 


\title{
Violence in North-American Indian Sports Games
}

\author{
Fabrice Delsahut \\ ESPE University Paris Sorbonne / L-Vis Lyon 1, France
}

\begin{abstract}
North American Indians have often been perceived as violent, bloodthirsty buman beings. The horrified fascination exerted by this violence on the European imagination takes hold of all historical accounts and lies at the heart of the smallest social productions. The sports games, whose imposing corpus is intriguing to the colonists, are also perceived as a cultural element of this gratuitous violence, a biological one, even, as inherent to their "wild nature". And yet, far from being instinctual, this violence takes on a ritual and propitiatory dimension that is at the same time at the service of private interests, but also, and especially so, of tribal ones.

By taking possession of the lacrosse game through its institutionalization, Canadians hope to control the violence of this emblematic game-ritual. Despite a deep transformation of the game, the instinctual manifestations in the buman relationships that are supposed to decline through the internalization of restrictions subsist. The original game still seems to express itself through this violence-based relationship, no matter how codified.

Drawing on archives ranging from missiological writings to anthropological documents, as well as on recent academic studies, this article tries to dispel the defining halo of a violence sometimes confused with distinct forms of aggressivity.
\end{abstract}

Keywords: Anthropology; Games; Lacrosse; North-American Indians; Rituals; Sports; Violence.

\section{Introduction}

During the times subsequent to their discovery, the American Indians are represented in a very inaccurate way by the explorers, the colonial administrators, the soldiers and the merchants, as well as by the Franciscan and Jesuit missionaries, who comment with plenty of details on the weirdness of their habits, behaviors and knowledge. For a long time, they are known only by means of accounts, ideas and symbols that distort, almost durably, their real image. This other, revealed according to the perception angle of the dominators, is described as an anthropophagic, naïve and cruel "savage," but as one who lives in harmony with nature. As many ways of life that will be condemned, nourishing prejudice and relegating the American Indian to an inferior rank. The warlike mores, extended to all the Indian nations, turn them into violent beings, as attested to by the Father de Smet in a letter dating from the $10^{\text {th }}$ of December 1854. Giving an account of a skirmish between Assiniboine and Arikara, he writes: "At the first discharge of guns and arrows, the twelve Assiniboine deputies lose their life. Their hair is being removed on the spot and their dead 
bodies horribly mutilated." 1 A soldier reports in the 1750 s on the practices of war, and especially the scalping:

When a war party has captured one or more prisoners that cannot be taken away, it is the usual custom to kill them by breaking their heads with the blows of a tomahawk [...] He quickly takes the scalp, gives the death cry, and flees at top speed [...] This horrible custom was practiced by these savages alone, and sprang from their own barbarism, for it seems never to have existed in any other nation, not even among nations who, like them, have never received any idea of civilized life. ${ }^{2}$

These writings will stereotype for a long time the conflict and domination situations, with a view of conformity to the images of the warlike savage circulated in Europe. This warmongering is, however, confirmed by numerous present-day researchers. ${ }^{3}$

This other humanity also reveals itself through its abundant ludic productions. The missiological writings describe the important corpus of games and the essential place held by these latter ones within the Indian communities. They also signify their inadequacy with regard to the religious values of the colonies. Two types of games are particularly denounced, namely gambling and warlike sports games. ${ }^{4}$ The former are perceived by the theocratic guides as frivolous activities, characteristic of laziness and idleness, the appanage of diabolical activities. The latter are decried for their violence. According to Jonathan Carver (1796), "They play with so much vehemence that they frequently wound each other, and sometimes a bone is broken." 5 John Pope, referring to the Creek ball game, reports in 1791 that "a dislocated join or fractured bone is not undercommon." 6 The explorer Nicolas Perrot is even more explicit about the warlike nature of the lacrosse game:

You hear the noise they make in clashing against each other, when they want to fend off the kicks in order to send that ball on the favorable side. When someone keeps it between his feet without wanting to let go of it, he has to avoid his opponents' continuous kicks to his legs; and, should he happen to be injured in this situation, it's on his behalf. There have been seen some who have had their legs broken, others, their arms, and some have even been killed. It is very common to see some of them

\footnotetext{
1 R. P. De Smet, "Quatorzième lettre du P. de Smet. Histoire d'un chef des Assiniboins," in Précis historique, ed. S. J. Terwecoren (Bruxelles, 1855).

2 J. C. B., Travels in New France by J. C. B. (Harrisburg: The Pennsylvania Historical Commission, 1941), 67-68.

3 Among which Gilles Havard, who addresses this issue in his work: Empire et métissages: Indiens et Français dans le Pays d'en Haut, 1660-1715 (Sillery \& Paris: Septentrion-Presses de l'Université de ParisSorbonne, 2003).

${ }^{4}$ The definitions selected are those proposed by Pierre Parlebas in his work Jeux, sports et societés. Lexique de praxéologie motrice. The sports game corresponds to "any codified motive situation of confrontation, named 'game' or 'sport' by the social authorities." The institutional sports game is "governed by an officially recognized authority (federations) and thus sanctioned by the institution; an institutional sports game is a sport." The traditional sports game is a game "often rooted in a long cultural tradition, but that has not yet been sanctioned by the institutional authorities."

5 Jonathan Carver, Travels through the Interior Parts of North America (Philadelphia: Key and Simpson, 1796), 237.

${ }^{6}$ John Pope, Tour Through the Northern and Western Territories of the United States of North-America (Richmond: John Dixon, 1792), 50.
} 
crippled for the rest of their days, and who have only underwent this at this kind of game, as an effect of their stubbornness. ${ }^{7}$

These writings are to be seen in relative terms, since the games are the mirrors of American Indian traditions where myths, punctual events related to intercommunity relationships, as well as laws and religious rituals coexist, and which present their complexity to transcribers whose prejudice distorts the collections. The very definition of the violence mentionned in these texts leads to confusion.

Violence is a multiform concept, acquiring various meanings according to the age and adopted viewpoint. It rests on the use of force. Violence's a-relational nature turns it into a destructive activity, arising from a poorly controlled, deregulated aggressivity. It finds its expression especially in the American Indian martial phenomenon. It can also be found again, in its symbolic form, with the appropriation of the lacrosse game by the Canadians. The aggressivity falls more under the category of affirmation of the self, of one's power in front of someone else. It is fundamentally relational. Well-dosed and controlled, it plays an essential part in the pursuit and reaching of objectives. It seems, then, that the games fall more-so under the category of a form of aggressiveness than under that of an individual or collective violence, directed towards the other or turned against oneself. Even though the internal logic of certain games explicitly stages the confrontation, these latter ones appear more as fostering the symbolic and ritual control of violence. The undeniable strenuous nature of the game pertains more to a personal search of accomplishment, to a ritual actuation of antagonisms present in the mythological stories and of a re-appropriation of Indianness by the Europeans. Multiple symbolic meanings and material interests are therefore hidden behind the kinship of warmongering and sports-games. In the absence of violence, maybe we should better see in these practices a plural aspect of aggressivity as perceived by the Anglo-Saxons, namely the aggressivity concerning the fact of attacking the physical and mental integrity of an individual and the aggressiveness falling under the category of combativity.

This analysis relies on various types of archives, among which are to be found the missiological writings ${ }^{8}$ that encompass, among others, anthropology and history, such as those compiled in "La relation des jésuites de la Nouvelle-France" from 1632 to 1672, as well as the documents collected by the anthropologists in the $19^{\text {th }}$ and $20^{\text {th }}$ centuries. ${ }^{9}$ These primary sources are cross-referenced with various documents, ranging from academic productions to pictorial documentations of the ethnographic artists of the $19^{\text {th }}$ century and of the early $20^{\text {th }}$ century.

\footnotetext{
7 Nicolas Perrot, Mémoire sur les moeurs, coustumes et relligion des sauvages de l'Amérique septentrionale (Leipzig \& Paris: Librairie A. Franck, 1864), 45.

8 Cf. The Jesuit Relations and Allied Documents, published by Reuben G. Twaites between 1896 and 1901 at Cleveland, who presents in 73 volumes the letters sent by the French Jesuits to the kingdom in the $17^{\text {th }}$ and $18^{\text {th }}$ centuries. The Jesuit Joseph François Lafitau publishes in 1724 Maurs des samvages américains comparées aux mours des premiers temps, starting from his experience at the Iroquois mission of Caughnawaga, between 1712 and 1717. The writings of Pierre-François Xavier de Charlevoix, Histoire et description générale de la Nouvelle-France, edited in 1744, leave remarkable information on the Western tribes. The archives of the US Army and of the US Office of Indian Affairs of the Commissioner of Indian Affairs also open the doors of the West in the 19th century.

9 See, among others, the works of George P. Belden, Carl Lumholtz, Lewis H. Morgan, and Nicolas Perrot.
} 


\section{A Domestication of Human Relations and of Violence}

\section{A. Reduction of Tensions}

The violence specific to certain sports-games pertains, first of all, to a will to reduce the tensions arising from situations as diverse as the need to assert oneself or to wage a war. True rites of initiation, they are, as emphasized by Royal B. Hassrick, "a culturally acceptable device for taming aggression, and had the additional value of teaching physical dexterity and mental alertness." 10 They can, therefore, be perceived as a tensional outlet or as a direct attempt at reducing the tensions. George Catlin thus reminds that "they are everlastingly practicing for want of other occupations or amusements in life." 11 John M. Roberts and Brian Sutton-Smith describe what they call "The conflict-enculturation". ${ }^{12}$ The members of a society practice games - usually sport-like - that function as an outlet for the conflicts generated by their type of education. Usually peace-loving, the American Indians of the Great Basin, of California and of the Plateau practiced pre-sport-like games, as well as games of dexterity not generating any violence. By contrast, the tribes of the Great Plains devoted themselves more to games which were about defending the honor of the tribe by all means. The varieties of games are therefore related to those of the types of education. From a semantic point of view, if the play is universal, the games are specific, as so many tribal habitus.

The agonistic games are a cultural response meant to domesticate aggressivity, to reduce the violence expressed in the inter- and intra-tribal conflicts. "Team games for boys were of a rough-and-ready nature, designed to offer excitement and fun as well as to encourage toughness and physical endurance." 13 They all refer to the notion of testing. Bernard Hailes ${ }^{14}$ shows that the Navajos practice a harsh training since the earliest age possible, and Walter Dyk ${ }^{15}$ quotes an old Navajo who talks about his races as a young man, his moccasins weighed down with sand, in order to keep his feet steady, and his mouth full of water, climbing on the hills, to develop his breath, running practically naked in the snow, in order to toughen up. Dorothea Leighton and Clyde Kluckhohn ${ }^{16}$ write that it is recommended to young people to wake up before dawn, to run almost naked, to roll in the snow, to shake the snow off the branches of trees on their back, to run holding pieces of ice in their mouth, to break the ice of rivers and ponds in order to bathe in them. Such a rigorous training prepares them for the summer practices like the race under the scorching sun, where the relationship of a magical nature with the father-star intervenes.

\section{B. Games and Means of Affirmation}

The games are also a means of self-affirmation, of gaining recognition. The courage in battle is, for the American Indians, the greatest virtue of man. They hold it in such high regard that they pay homage to it even in an enemy. Being considered brave is an extremely important honor, worthy of the greatest efforts. Only those that have proven themselves are acclaimed. This virtue, explains Royal B. Hassrick, is instilled into children since the earliest

\footnotetext{
${ }^{10}$ Royal B. Hassrick, The Sioux: Life and Customs of a Warrior Society (Norman: University of Oklahoma Press, 1964), 151.

${ }^{11}$ George Catlin, Letters and notes on the manners, customs, and conditions of North American Indians, vol. II (New York: Dover publications, 1973), 123.

12 Roberts John M. \& Sutton-Smith Brian, “Child training and game involvement.” Ethnology1 (1962).

${ }^{13}$ Royal B. Hassrick, The Sioux: Life and Customs of a Warrior Society, 144.

${ }^{14}$ Berard Haile, "Navaho Games of Chance and Taboo," Primitive Man 6 (1933): 35-40.

${ }^{15}$ Walter Dyk, Old Mexican, Navaho Indian. Son of Old Man Hat (New York: Harcourt, Brace, 1938), 69.

${ }^{16}$ Dorothea C. Leighton \& Clide Kluckhohn, Children of the People (Cambridge: Harvard University Press, 1948), 57.
} 
age. It appears in the stories of the elderly, in the rules of conduct issued by parents, as well as in children's games. "Bravery was not something heard about but never seen; bravery was a way of being, of acting, of doing. And small boys were guided and encouraged to behave fearlessly." 17 The "Swing-kicking game" is one of the toughest games. Two rows of players face each other and confront themselves, protected only by a tunic, trying to make their opponent fall. Everything seems to be allowed:

Kicking from behind the knees was a good way of throwing an opponent, and once down he was grabbed at the temples with both hands and kneed in the face. Once released, the bloody victims would fight on, kicking and kneeing and bleeding until they could fight no longer. The game was over when one side retreated or someone yelled "let us stop". ${ }^{18}$

This game allows the young American Indian to convince himself of his own bravery. He seeks the recognition of the others as so many means to prove himself. For there, more than elsewhere, the success of the personal affirmation allows him to win everything, just as the failure means losing everything. These types of brutal games look like final acts of courage and will in the teenager, before the "first counted blows"19 rush the young hunterwarrior into adulthood. Participation in the games allows children and teenagers to enter, symbolically, the world of the grown-ups, to the extent that every game contains the tribal virtues. Thus, the team games that generally refer to notions of collectivity, of mutual help and cohesion, also value the individual act. The same goes for all actions in war. A great feat of arms consists of "counting a blow." 20 A blow is valid only if another warrior witnesses it and testifies to it, and the feats are being attributed different values. But this individuation cannot take place to the detriment of the collectivity. The individuation must be perceived as the quality of a human being of becoming an individual, synonymous both of mental and of physical development. In a social structure where the individual is often disregarded (for the benefit of the clan, the group, the tribe or the family, war), the hunt or the game offers a privileged space for "accomplishing oneself" and existing as a being before the eyes of the other members. It is all the more important for the young children and grown-ups.

Since his earliest childhood days, the young American Indian is trained to dominate himself, to submit his body and his mind, his judgment and his senses to the toughest tests, in order to make them impervious to weakness. And, since the cradle, this healthy constraint acts upon him. To the American Indians, the game has an immediate and essential value for the physical development of the young child. This role seems primordial, given how harsh the living conditions sometimes are. One finds, thus, numerous games focusing on endurance, strength and dexterity, but also on moral strength. But, beyond the will to adjust the young generations to the requirements of the environment, the game is, moreover, necessary to the acquisition of the tribal values (the social side of adaptation) and it guarantees the cohesion of the individuals. The fact of "being born an Indian" is not enough. They must learn to live with that social determinism. Many games of aggression are

\footnotetext{
${ }^{17}$ Royal B. Hassrick, The Sioux: Life and Customs of a Warrior Society, 33.

${ }^{18}$ Ibid., 151.

${ }^{19}$ Among the tribes of the Plains, the result of a battle or foray was of less importance than the bravery of the participants. Nothing testifies more to this state of mind than the habit of "counting a coup" (phrase of French origin). A warrior of the plains counted a coup when he managed to touch an enemy with a hitting stick (a long and thin pole with, sometimes, a curved end), with a spear, an arrow or any other object. Only the risk taken was valuable, counting a coup on an armed enemy was worthier than simply killing him, especially with an arrow, that is, from a distance.

${ }^{20}$ George Bird Grinnell, "Coup and Scalp among the Plains Indians," American Anthropologist 12 (1910): 296-310.
} 
thus reserved to the young boys. The "Fire throwing game" described by Royal B. Hassrick $^{21}$ opposes two teams separated by two mounds of branches. Once the branches have caught fire, every participant takes hold of several burning pieces and he tries to encircle the opposing team, hitting them with the firebrands. If none of the two teams withdraws and they meet in the center of the playing field, there follows a great battle amidst smoke and burning embers. In this type of hand-to-hand fight, as soon as the "enemy" was touched two or three times, the torch is extinguished, and it is then his turn to receive his part of burns, until the torch of the opponent is extinguished in its turn.

The bellicosity of the young players falls under the category of socially learned behavior (as defined by Albert Bandura ${ }^{22}$ ) just like any other behavior. This behavior is, at the same time, the result of a direct learning process dictated by the elders, but also, and especially, the outcome of an indirect learning by observation, then imitation of models to whom the young can refer to, for instance during the grown-ups' ball games.

\section{Stakes and Wagers}

Compared to stakes as important as healing, fertility, mortuary accompaniment, harvests and others, there can be no real rival pretensions. Things are, however, different when it comes to material stakes. True American Indian facts and uniformly spread across the North-American continent, the wagers seem to add more importance and a general legitimacy to the gatherings. This especially answers a tribal need that a good number of authors have mentioned. The reverend Beauchamp summarizes in 1896 the general attitude of the Indians of North America towards wagers:

Our aborigines had an innate love of gambling, and the idea of gain or loss entered into most of their simple sports. The Iroquois were accustomed, as our western tribes are yet, to stake everything on games of chance or skill. The turn of the plum stone might give them poverty or wealth. It certainly would give them the excitement they craved. ${ }^{23}$

Unlike our present-day athletes, the players are not being paid. Wagers therefore provide an opportunity to win additional material goods, even substantial ones, thanks to their athletic exploits. The gatherings occasioned by the ball game bring together several hundred players and several thousand spectators. George Catlin relates that, among the Choctaw, "It is no uncommon occurrence for six or eight hundred or a thousand of these young men, to engage in a game of ball, with five or six times that number of spectators, of men, women and children, surrounding the ground." 24 The wagers are, therefore, numerous, and one can easily guess the keen interest generated by this. The excitement of the spectators and betters takes a great part in galvanizing the players and in increasing the conflictual behaviors on and off the playing field.

The fact that the American Indians wager to such an extent represents more the sign of a conflict, opposing self-expression to self-denial, than a will to obtain profit. In fact, the material goods stay within the community. The wager related to the game is part of a kind of "circular economy." The winnings return, indirectly, to the community, and thus contribute to nourish the general and common material goods. This practice is an integral part of Indian American culture and it is, in fact, upheld, even sustained, by the elders and

\footnotetext{
${ }^{21}$ Royal B. Hassrick, The Sioux: Life and Customs of a Warrior Society, 144.

22 Albert Bandura, Social Learning Theory (Englewood Cliffs: Prentice Hall, 1977).

${ }^{23}$ William M. Beauchamp, "Iroquois Games," Journal of American Folklore 35 (1896): 277.

${ }^{24}$ George Catlin, Letters and notes on the manners, customs, and conditions of North American Indians, vol.II

(New York: Dover Publications, inc., 1973), 123.
} 
by the medicine men who usually officiate at ceremonies. It is more than a spice; it is part of the game and of the life of the community. This reciprocity-principle constantly reminds the individual that the accumulation of goods only makes sense in the context of redistribution. The Europeans, and more especially the missionaries, are the ones who have brought, a few years later, their own criteria of immorality into the practice of wagers.

The group-identity falls under the category of the conscience of a group-unity. The opportunities of reinforcing the ties of tribal belonging are echoed in every type of game. The lacrosse games, the ultimate collective games, provide a favorite field of expression for this type of relationships. According to Michael A. Salter: "The group cohesiveness reached beyond those directly involved with the game, to encompass the entire tribe (...) The feeling of unity was further reinforced by the numerous intratribal games $(\ldots)$ and the stakes placed on intertribal games." Concerning wagers, he specifies that "if lost, could precariously tilt the delicate economic balance of tribes." 25 The vital feeling of unity, associated to the amount of the wagers and to the invectives or cheering of the audience can, therefore, only make the gatherings a little more animated.

\section{Games and War}

The prevalence of war in the description of the savages' mores holds the attention of the first Occidental observers. "The primitive societies, writes Pierre Clastres, are violent societies, their social being is a being-for-war." 26 This especially warlike character strikes in a quasi-unanimous fashion and it finds itself notified at the very heart of the physical practices. The violence inherent to certain games acquires, then, a more metaphorical significance. The latter are perceived as an image of war or, more exactly, as an ideal modality of bellicosity. For Eric Taladoire:

Even if that only represents one of the aspects of the game, by its function of confrontation, sport constitutes a factor of cultural or social identity, a factor of cohesion of a group in front of the surrounding world and, consequently, a substitute or derivative of open war. ${ }^{27}$

This relationship is highlighted in the $17^{\text {th }}$ century by Nicolas Perrot:

In this lacrosse game, you would think seeing the like of two parties that would want to fight. This exercise contributes a lot to make the savages alert and ready to fend off adroitly a blow to the head on the part of their enemy, when they find themselves involved in the fight; and, unless being warned that they are playing, one would really think that they are fighting in open country. 28

For the South-East American Indians, war is such an obsession that some of their games imitate the harshness of battle. Beyond the simple image of war, they offer practical ways of confrontation. For Johan Huizinga, "the frontier of what the game allows is not necessarily situated below the bloodshed, not even below the deadly blow." 29 According to William M. Beauchamp, "as the Iroquois children were to become warriors, many of their

\footnotetext{
${ }^{25}$ Michael A. Salter, "The effects of acculturation on the game of Lacrosse and on its role as an agent of Indian Survival", Canadian Journal of History of Sport and Physical Education 1 (1972): 29.

26 Pierre Clastres, Archéologie de la violence. La guerre dans les sociétés primitives (La Tour-d'Aigues : L'aube, 1977), 238.

${ }^{27}$ Eric Taladoire, "Les jeux de balle en Amérique Précolombienne”, La Recherche 272 (1995).

${ }^{28}$ Nicolas Perrot, Mémoire sur les moeurs, coustumes et relligion des sauvages de l'Amérique septentrionale, 45.

${ }^{29}$ Johan Huizinga, Homo Ludens (Paris: Gallimard, 1995), 150.
} 
sports were of a savage and warlike nature." 30 The warlike aspect is also evoked among the Creek (hótti icósi “younger brother of war") or the Cherokee (da-na-wah'uwsdi' «small war») in order to designate the ball game. The Cherokee metaphorical definition seems to abide by the socio-political organization into two divisions of the tribe: the whites, consisting of elders or middle-aged men, metaphorically representing peace, and the reds, consisting of young people, qualified as "warriors," symbolizing war. Emmanuel Désveaux points out, however, that: "the adjustment between the equation of war and ball game, on the one hand, and the sociological dualist division, on the other hand, is complemented by a reversal: the real war is older compared to the ball game, but, in the ball game, the younger people are the warriors. ${ }^{31}$ This proximity with war is also being expressed in the prescriptions and prohibitions that the players were required to observe before the gatherings, as well as before certain raids (i.e., sexual abstinence, fasting,...).

\section{E. Ritualized Violence}

The games go beyond this mere ludic aspect and mix mythical-religious and propitiatory practices, the propitiatory act aiming at obtaining a divinity's favor during a rite, an offering or a game. Numerous games find their origins in myth, and participation in these games is supposed to be in agreement with the divine wishes. For Emmanuel Désveaux, the NorthAmerican Indian ball game "constitutes one of the keystones of the Pan-American mythical-ritual edifice." 32 It seems to be located at the nexus of the ritual and the ludic and it concerns all the socio-cultural components of daily life. The games express themselves in a great number of tribal myths and are embodied in numerous rites. Their function is that of being liked by and pacifying to the spirits. The measure of this very strong connection between the games and the dualist principle of the New Continent can be taken in its ludicritual device. Thus, they occupy a major place in the ceremonies related to death, birth, harvest, hunt, war, and other community events. The religious significance of the game increases its status. The victory attracts the greatest favor of the gods and keeps at bay for a while the evil spirits and their retinue of omens.

Among the numerous rites associated to the games, some are intended to posit the transcendence of the sacred by separating it from the secular player, and others allow the players to participate in the sacred world. In the first category, numerous rites establish interdictions that are related to taboos. This asceticism can take on moral virtues, having a foundational value for the group. Among the rituals that lead to a direct participation in the sacred world, prayer, dancing, and offerings are means allowing to obtain the forgiveness of the divine powers. These rituals prompt the spirits to invite themselves to the humans, to mingle with them. The "mythical-ritual" violence inscribes itself, then, into two particular fields: that of sacrifice and that of commitment.

Sacrifice represents a religious rite par excellence. According to Marcel Mauss ${ }^{33}$, its purpose is that of interposing a victim between the secular world and the sacred world that must get in touch with each other. It allows to create a connection with the spirits, by pleasing them. James Mooney ${ }^{34}$ describes a scarification ceremony where an official makes use of a Kanuga, a kind of small comb with seven very sharp teeth, made of bones from turkey legs. The official or the shaman uses this tool to make scarifications along the arms

\footnotetext{
30 William M. Beauchamp, "Iroquois Games," 273.

31 Emmanuel Désveaux, Quadratura Americana (Genève: Georg Éditeurs, 2001), 301.

32 Ibid., 295.

${ }^{33}$ Marcel Mauss \& Henri Hubert, "Essai sur la Nature et la Fonction du Sacrifice," L'Année sociologique 2 (1899).

${ }^{34}$ James Mooney, “The Cherokee Ball Play,” The American Anthropologist 2 (1890): 121.
} 
and legs of every player. These marks are long and pierce the skin just enough to allow the blood to ooze. This painful ritual continues until twenty-eight marks are made, respectively on the higher arm, the forearm, the thigh and the calves or shins. In the end, blood is dripping on almost all the parts of the player's body; unavoidable consequence of the ritual meant to ensure the success of the game. This very same ritual was noticed in April 1828 by Captain Basil Hall, from the Royal Navy, during the ceremonies preceding a lacrosse game at the Creek. He writes in this respect that the players:

Deliberately allowed their limbs to be scratched or rather scarified by some old Indians (...) it was a hideous and frightful scene (...) I was told that these scarifications and bleedings render the men more limber and active and bring them into proper condition to undergo the exertion of the ballplay on the following morning. ${ }^{35}$

This violence inherent to the rite, and that it is found to a higher degree in the sacrificial rites of the Central American Indian ball games, represents a victimary mechanism such as described by René Girard ${ }^{36}$. Violence, then, creates the sacred.

Another form of sacrifice can be expressed in the commitment expressed by everybody. The Father François Joseph Le Mercier explains that during the month of May 1637, just before the planting season, the American Indians "had tired themselves to death playing crosse in all the villages around here, because this sorcerer had affirmed that the weather depended only upon a game of crosse." 37 Through people's commitment to the games, we notice the very strong connection between games, and especially ball games, and the dualist principle of the New Continent. "The game operates, in a dynamic, highly cultural manner, the mediation between the heavenly and the chthonic field, perceived as radically antagonistic." 38 People's commitment to the game has therefore the role of distracting and pacifying the enemy cosmic entities and of dissuading them from directly confronting each other, which would have disastrous effects for human beings.

These "game-like" rituals raise again the question of the definition of violence. Through the ritual game emerge at the same time a "symbolic" violence, staged, dramatized, "played," 39 and a real violence, with all its savagery, despite its being disguised by the ceremonial and legitimized by the representations that accompany it and the possible taming of the death instinct. Françoise Héritier sees rather in the sacrificial rite a form of sublimation of violence. She shows that "the rite has as its first effect the limitation of this violence: that the violence contained in the sacrifice is, first of all, a violence contained by the sacrifice." 40 By curbing violence, the ritual game creates a peace area. This is also the case of various game-based conflict-solving procedures that shall be addressed below. If violence, as defined in our introduction, is situated outside the social frameworks that lie at the basis of the individual's belonging to humanity, and if the game, according to the works of C. Lévi-Strauss, ends in the dissymmetry of an inegalitarian domination (despite the initial equality of the democratic type), the association of the two can only generate chaos. In front of the mythical-religious stakes, by associating the game (or at least the physical practices that bear some resemblance to games) to the ritual, those who officiate end up in

\footnotetext{
${ }^{35}$ Basil Hall, Travels in North America in the years 1827 and 1828 (Edinburgh: Printed for Cadell and Co.; London: Simpkin and Marshall, 1929), 294-295.

36 René Girard, Violence and the Sacred (Baltimore: John Hopkins University Press, 1977).

${ }^{37}$ Reuben G. Thwaites, The Jesuit Relations And Allied Documents: Travels and Explorations of the Jesuit Missionaries in New France, 1610-1791, vol. XIV (Cleveland: The Burrows Brothers, 1898), 47.

${ }^{38}$ Emmanuel Désveaux, Quadratura Americana, 299.

${ }^{39}$ See Claude Lévi-Strauss, La Pensée Sauvage (Paris: Plon, 1962), 44-46.

${ }^{40}$ Françoise Héritier, De la Violence II (Paris: Odile Jacob, 1999), 138.
} 
the symmetry of an egalitarian and pacifying communion. Despite the inequality of a demonocracy-related model specific to any rite, the "game" of seduction operates in the sports encounter thanks to the instrumental aggressivity ${ }^{41}$ of the participants and it enables, perhaps, to appease the supernatural powers.

At the level of jurisdiction, fate, gambling or sports games, wagers, provocations, battles, and divine decisions find themselves brought together within a single conceptual sphere. The judicial games do not have, thus, for their object to establish which party is within its rights, but which one is the most skillful or the strongest. So that the winner can be the one who, with respect to the facts that have necessitated appealing to the judicial duel, has transgressed a rule. The parties confront each other in order to obtain from the gods a decision with sacred value, by the test of victory or defeat. This decision can be caused by a stroke of fate, by the experimentation of forces measuring up against each other in words or in arms. This is an instance of a conflict-solving procedure by deflection: the facts making the object of the dispute are not directly examined, and the conflict is defused by simply resorting to a game external to the dispute itself. This ordeal involves the fact that the ludicmotive qualities of the winner are supposed to be a divine sign of his righteousness. In order to rightly understand this particular relation to the divinities, explains Johan Huizinga, "we must, in a nutshell, set aside our conceptual distinction of the legal, religious, and political fields. What we call 'right' may, from an archaic point of view, be called just as well 'the divine will' or 'the evident superiority.' Fate, fight and the eloquent word are, in the same way, 'means of proving' the will of the gods." 42 In the impossibility of rational evidence, the intervention of the supernatural is thus invoked.

These "judicial" games representing legal ways of conflict-solving can be found under various forms, such as the fight among the Inuit ${ }^{43}$ or the archery among the New England American Indians. ${ }^{44}$ The lacrosse is also used in order to prevent the aggressions and the territorial disputes between the tribes. H.S. Halbert thus relates "The Great Ball Play and Fight on Noxubee," a lacrosse game opposing the Creek to the Choctaw during four hours, towards 1790, in Mississippi, in order to establish the rights concerning a beaver pond. ${ }^{45}$ With respect to the judgments in the "Eskimo societies," Marcel Mauss writes:

The ceremonies of reception of strangers in Greenland, Baffin Island and King William Island, formerly, in Alaska, regularly included wrestling sessions. It is even claimed, not without exaggeration, doubtlessly, that, when a group came to visit a neighboring station, the regulated duel or the violent game that took place between two chosen champions ended in the death of one of the fighters. ${ }^{46}$

Céline Petit mentions an Inuit game related by Knud Rasmussen in 1929, occasioning heated exchanges and demonstrations of force. The taptaijaaq game, organized on the occasion of the winter festivities, is a kind of "Blind man's bluff" marked by a strong

\footnotetext{
${ }^{41}$ The instrumental aggressivity, which is premeditated (in order to obtain something) without the desire to hurt someone else, is being distinguished from the emotional aggressivity, underpinned by anger (in order to cause physical or psychological damage to someone else).

${ }^{42}$ Johan Huizinga, Homo Ludens,153-154.

${ }^{43}$ Norbert Rouland, "Les Modes Juridiques de Solution des Conflits chez les Inuits," Etudes Inuit 3 (1979).

${ }^{44}$ Thomas Morton, "Manners and Customs of the Indians (of New England)," in The Library of Original Sources, ed. Oliver J. Thatcher (Milwaukee: University Research Extension Co., 1907), 360-377.

${ }^{45}$ Horatio Bardwell Cushman, The History of the Choctaw, Chickasaw, and Natchez Indians (Norman: University of Oklahoma Press, 1999), 131-133.

${ }^{46}$ Marcel Mauss, "Essai sur les variations saisonnières des sociétés eskimos. Étude de morphologie sociale " L'Année Sociologique 9 (1906): 55.
} 
physical brutality. One of the participants, blindfolded, is placed at the center of a group of players that try to hit him, often at the level of the temple or of the shoulder. When one of them manages to do that, the blindfolded player can try to catch one of the participants (if possible, his aggressor) in order to hit him in his turn.

This collective game, which could thus take on a dualist dimension (under the supervision of the group), represented a favorable framework for the expression of interpersonal rivalries and to the settlement of certain disputes involving male or female individuals. The women themselves were susceptible of legitimately exchanging blows within this festive setting. ${ }^{47}$

\section{F. Channeled Violence}

This violence is, nevertheless, channeled. John Pope emphasizes that, despite the serious injuries that the lacrosse players inflict to one another, "Suffer what they may, you'll never see angry look or hear a threatening word among them." 48 Indeed, given their demanding nature, the great number of players on the field, the lack of standardization and the small number of referees, and in the absence of players' equity- and loyalty-based sportsmanship, these games can easily turn to chaos. In 1684, Nicolas Perrot, a merchant and agent of the Government, describes the good graces with which the Ontario Hurons accept the injuries or defeats during a lacrosse game. He reports that:

No matter what accident this game could cause, they attribute it to the fate of the game, and do not harbor any hatred against one another. The harm is for the wounded, who have such a satisfied air with that as if nothing at all would have happened to them, thus giving the appearance of being very brave and of being men. ${ }^{49}$

A respectful attitude is expected by all. In the opposite case, besides the fact of dishonoring the one who misbehaves, it's also the team, the tribe or the family who suffer the insult. This leads to the creation of social pressure acting upon the player. Francis B. Mayer, witness to an encounter among the Dakotas in 1851, writes: "No one is allowed to become angry or to be offended by no matter what brutal treatment he may receive." 50 Concerning the Swing-kicking game previously mentionned, according to the words of Iron Shell, "some boys got badly hurt, but afterwards we would talk and laugh about it. Very seldom did any fellow get angry." 51

This concern for equity and loyalty is astonishingly counterbalanced by the usual recourse to cunning and trickery. Thus, the violence of the game is often brought back to a more playful, humorous dimension, by the action of trickery that legitimizes the tribal myths and stories. For John Long:

The Indians play with great good humour, and even when one of them happens, in the heat of the game, to strike another with his stick, it is not

\footnotetext{
${ }^{47}$ Céline Petit, Jouer pour être heureux. Pratiques ludiques et expressions du jeu chez. les Inuit de la région d'Iglulike. (Arctique oriental canadien), du XIXe siècle à nos jours (Thèse de doctorat, Faculté de Théologie et de Sciences Religieuses, Université Laval, Québec \& Université Paris Ouest Nanterre La Défense, 2011): 202-203.

${ }^{48}$ John Pope, Tour Through the Northern and Western Territories of the United States of North-America (Richmond: John Dixon, 1792), 50.

${ }^{49}$ Nicolas Perrot, Mémoire sur les moeurs, coustumes et relligion des sauvages de l'Amérique septentrionale, 45.

${ }^{50}$ Francis B. Mayer, With Pen and Pencil on the Frontier in 1851: The Diary and Sketches of Franck Blackwell Mayer (St. Paul, Minnesota Historical Society, 1932), 158.

51 Royal B. Hassrick, The Sioux: Life and Customs of a Warrior Society, 146.
} 
resented. But these accidents are cautiously avoided, as the violence with which they strike has been known to break an arm or a leg. ${ }^{52}$

Violence or trickery must, nevertheless, stay at an acceptable level, as reminded by Lt. George P. Belden concerning a ball game:

In this game everyone must keep his temper, and any stratagem is allowed, so the ball is not touched with the hands. It is not suffered, however, for anyone to hit another over the head, or on the body with sticks or the bands, but if you can upset a gamester by running against him it is esteemed fair. When either party cheats, foul is called by the opposite party, when the game ceases until the judges decide the matter. If it is a foul play the game is given to the other side. No one thinks of disputing the judges' decision, and from it there is no appeal. ${ }^{53}$

This individual responsibility in terms of fair-play must be contrasted with today's institutional practices, where only the power relationship seems to exist and a greater proportion of judges per player is attributed.

\section{The Lacrosse Game: Between Symbolic Violence and Physical Violence}

\section{A. The Younger Brother of $W$ ar}

The Indian lacrosse game is one of the oldest team games on the American continent, since the origins of this sport go back to the $11^{\text {th }}$ century in Mesoamerica or Mexico. ${ }^{54}$ The players, equipped with a stick whose end is curved and closed by a net, try to make a ball pass between the goal posts of the opponent. The remarkable character of the game amounts largely to its violent nature, mentioned by numerous observers and that has marked collective consciences. George Catlin notes:

Hundreds are running together and leaping, actually over each other's heads, and darting between their adversaries' legs, tripping and throwing, and foiling each other in every possible manner, and every voice raised to the highest key, in shrill yelps and barks. ${ }^{55}$

The generic name of lacrosse refers to an identical form of collective game, consisting of as many practices as ethnic components. For Emmanuel Désveaux, the North-American ball game:

Seems to be forever fluctuating, as if all the possible variations had been created starting from the combination of some basic elements, such as the dimension of the playing field, the number and the sex of the participants, the shape of the accessories, the occasions to play, etc. There were not two groups who shared the same rules or ways in that field. Besides, several of them often coexisted within one and the same group. ${ }^{56}$

The colonists' interest in this game will seriously undermine this variable character,

\footnotetext{
52 John Long, Voyage and Travels of an Indian Interpreter and Trader, describing the manners and customs of the North American Indians (London: printed for the author, 1791), 52.

${ }^{53}$ George P. Belden, Belden, the white chief: or, Twelve years among the wild Indians of the plains (Cincinnati, New York: C. F. Vent, 1870), 40.

${ }^{54}$ Thomas Jr. Vennum, American Indian Lacrosse, Little brother of war (Washington: Smithsonian Institution Press, 1994), 28.

55 George Catlin, Letters and notes on the manners, customs, and conditions of North American Indians, 439.

${ }^{56}$ Emmanuel Désveaux, Quadratura Americana, 289.
} 
especially at the moment of its institutionalization.

\section{B. The Sportive Colonization}

The lacrosse game is the most emblematic game of the American Indians. It fascinates just as much as it is decried. This ambivalence of stories will result in a form of symbolic violence through its appropriation by the dominant culture. This "sportive colonization" is thus expressed by the Canadian William George Beers, who will be the first to create rules for this game:

The present game, improved and reduced to rules by the whites, employs the greatest combination of physical and mental activity white men can sustain in recreation, and is as much superior to the original as civilization is to barbarism, baseball is to its old English parents of rouders, or a pretty Canadian girl to any uncultivated sqwaw. ${ }^{57}$

He also states with respect to the game that "Just as we claim as Canadian the rivers and lakes and land once owned exclusively by Indians, so we now claim their field game as the national field game of our Dominion." 58

Besides the symbolic dispossession of the most representative game of their culture, the American Indians will also, ironically, be used as foils to promote the latter and the national interests that are related to it. "It seems apparent that the colorfulness of the native and the uniqueness of his game were deliberately used to promote the Dominion abroad and to foster nationalism at home." 59 William G. Beers, a fervent nationalist, organizes tours to Canada, America, and Europe, involving American Indians and Canadians. In 1876, a team consisting of twelve Canadian players from the Montreal Lacrosse Club and thirteen Iroquois went to Ireland, Scotland, and England for a series of exhibition games whose culmination was the encounter before Queen Victoria, at Windsor Castle. Besides the fact of promoting this sport in becoming, the implicit objective is that of encouraging an important segment of the English population to immigrate to Canada, an underpopulated country. ${ }^{60}$ The exotic character is widely promoted, at the expense of the athletic qualities of the American Indians. "The value of the native player on this type of trip obviously lay more in his appeal to the spectator as an Indian, than in his ability as an athlete." ${ }_{11}$ After the assimilation of their game to Canadian nationalism, another form of violence is exercised through the utilization of the picturesque connected to "their savage enigma", to reuse Victor Segalen's expression" ${ }^{62}$. During a tour of the Shamrock Lacrosse Club to the United States in 1871, the Caughnawaga travel as "sparring partners" for the Montreal club. "While the Indian players were undoubtedly the drawcards on these trips, they frequently found themselves witnessing, rather than participating in international matches." 63 The visible signs of Indianness are showcased and, if they are forgotten, this generates numerous disappointments. "The people were sorely disappointed in the appearance of the Indians.

\footnotetext{
${ }^{57}$ William George Beers, Lacrosse. The National Game of Canada (Montréal: Dawson brothers, 1869), 3233.

58 The Montreal Gazette, August 8, 1867.

${ }^{59}$ Michael A. Salter, “The Indian Athlete: Exploiting or Exploited?," Paper presented at the $4^{\text {th }}$ Annual Convention of the North American Society of Sport History (Eugene, Oregon, June 17-19, 1976): 16.

${ }^{60}$ Thomas Vennum, American Indian Lacrosse, Little brother of war, 266-267.

${ }^{61}$ Michael A. Salter, "The Indian Athlete: Exploiting or Exploited?": 14.

62 Victor Segalen, Hommage à Gauguin, l'insurgé des Marquises (Paris: Magellan \& Cie, 2003).

${ }^{63}$ Michael A. Salter, “The Indian Athlete: Exploiting or Exploited?”: 13.
} 
The later played in neat well-cut uniforms and... wore no feathers or warpaint." 64 The American Indians represent, from now on, a non-negligible part of what might be called the Canadian national folklore. They belong to the history of the country and must, therefore, conform, like all folklore activities, to the expectations connected to the latter (attire, ceremonies...).

This symbolic, even psychological violence perpetrated against the heirs to the game ${ }^{65}$ culminates in rule IX, titled "Miscellaneous," of the first regulations, where it is explicitly written, in section 6: "No Indian must play in a match for a white club, unless previously agreed upon." The status of sparring partner or of circus freak is accepted during the exhibition games, but that of player is denied to them within the national championship.

\section{The Control of Violence}

The choice of the lacrosse game as a national sport by William G. Beers is due, first of all, to its popularity. Numerous writings preceding the ones of Beers mention the interest the colonists show in this game, whose unique character resides in its speed, its spectacular nature and its easily graspable rules. Beers sees all the educational potential of the game, which will be qualified as the "fastest sport on two feet" and which James Naismith, inventor of basketball, will describe as "best of all possible field games."

The institutionalization of the practice as devised by Beers would, at the same time, tame the savagery of the environment, but also the potential savagery of interindividual relationships, the savagery of physical combat and of bodily collisions. "The ritualization of the sports confrontation fosters the participants' internalization of the antagonistic norms prescribed by society and it develops the desired 'polishing' of behaviors." 66 According to Norbert Elias' theory ${ }^{67}$, by regulating the physical confrontation, the sports institution acts as the relay of the state power, which can thus control the exercise of brutality on the bodies and be the only one to hold its legitimacy. The creation of rules is likely to reduce the confrontation, by limiting its duration and specifying its technical conditions. The euphemizing of violence contributes thus to civilizing the mores, be they savage or Canadian.

To correspond to the expectations of a sportization, the traditional game must adhere to ethical imperatives reclaimed as having a foundational value. Sport is associated to health and to morality, and the rough character of lacrosse, reported by the first writings and noticed afterwards, cannot, as such, correspond to the laws of the Stadium. William George Beers saw the necessity of its regulation, because it was far too often undisciplined and violent. He even wrote that the purpose is to make a "less savage" sport out of it. He wants thus to introduce a scientific element which, he thinks, is a means for young men and women to build their character. In spite of everything, Beers faced the social context of the time. He was aware of the possible drifts of the lacrosse game, since "it is a common perversion of the game to be made violent by unscientific and young players." 68 His efforts in order to eliminate all violence from the game (without prohibiting virile body contact), were nevertheless meant to fail, in an age where ethnic and religious conflicts found an outlet in the games between teams coming from antagonistic groups. The aggressivity specific to the game represents thus a catharsis, both for the participants and the spectators,

\footnotetext{
${ }^{64}$ Alexander M. Weyand and Roberts R. Milton, The Lacrosse Story (Baltimore: Garamond/Pridemark Press, 1965), 105.

${ }^{65}$ For numerous American Indian nations, the game is a divine gift.

66 Pierre Parlebas, Jeux, sports et sociétés. Lexique de praxéologie motrice (Paris: INSEP, 1999), 99.

${ }^{67}$ Norbert Elias, The Civilizing Process (Oxford: Blackwell, 2000).

${ }^{68}$ William George Beers, Lacrosse. The National Game of Canada, 46.
} 
necessary in these times of conflicting social and religious relationships. This violence will make the game popular and ensure its continuity. In his writings on lacrosse, Beers manifested, in many respects, attitudes and opinions typical of the English Canadian elite of his time. He brought a robust Christianity to the support of the British conception, expressed his deep belief in the necessity of order and states that science and the scientific methods are the keys to progress. According to Beers, the Indian plays lacrosse "mainly by instinct $[\ldots]$ but the Indian never can play as scientifically as the best white players". ${ }^{99} \mathrm{He}$ writes further on that "If science is to be developed, rough brute force play must end; not the hard running, not the occasional honest shoulder encounters, but the slashing and swiping and wounding by crosses". ${ }^{70}$

Several years later, in 1883, Beers acknowledged the limitations inherent to the regulations and to "civilization" in the Canadian mentality. "Canadian sports, however, have a character of their own. They smack more of the ungoverned and ungovernable than the games of the Old World, and seem to resent the impost of regulations." 71 As writes JeanPierre Augustin, “The relative keeping at bay of violence in the regulated practices doesn't come into contradiction with the conservation of violent confrontations on the playing field and of acts of violence around the stadiums." ${ }^{\prime 2}$ The aggressive acts persisted, thus reflecting the difficult pacification of the social life.

\section{The Ungovernable}

Nowadays, it seems that the current institutional sports practice is significantly different from the original American Indian game. But can we really talk about an epistemological break generated by the sportization of lacrosse or, rather, by a process of sports hybridization between the two practices? The lacrosse seems to have preserved a degree of athletic indigenousness, especially through its relatively violent aspect, always present and which its institutional "taming" was unable to contain.

At the moment of quick development of the lacrosse, at the end of the $19^{\text {th }}$ century and at the beginning of the $20^{\text {th }}$ century, its violent aspect was always present. And yet, the 1868 regulations took into account this particularity, since rule XVIII, concerning Rough Play, mentions that: "No player shall hold another with his crosse, nor shall he grasp an opponent's stick with his hands, under his arms, or between his legs; nor shall any player hold his opponent's crosse with his crosse in any way to keep him from the ball until another player reaches it. No player shall deliberately strike or trip another, nor push with the hand; nor must any player jump at to shoulder an opponent, nor wrestle with the legs entwined so as to throw his opponent." Despite everything, towards the mid-1870s, numerous newspaper articles relate gaming incidents having to do with the incompetence of the referees and with especially rough, even violent behaviors of the players. Between 1867 and 1885 , the incidents related to disputes or to rough play during the championship are at least two times as many as those revealed during the exhibition games. Whereas the 1868 regulations mention the rules concerning "Rough Play (Rule XVIII), Threatening To Strike (Rule XIX) and Foul Play (Rule XX)", the 1878 ones complete the rules already known and add new ones related to "Deliberate Charging (Rule XX), Crosse Check (Rule XXI) and Interfering (Rule XXII)." The emergence of these new rules reflects the increase of aggressive and transgressive behaviors. But the latter are much appreciated by the

\footnotetext{
${ }^{69}$ Ibid., vii.

${ }^{70}$ Ibid., 57.

${ }^{71}$ William George Beers, Over the snow, or, The Montreal carnival (Montréal: W. Drysdale and J. Robinson, 1883), 15.

${ }^{72}$ Jean-Pierre Augustin, "Sports, violences et territoires", Cahiers de géographie du Quebec 150 (2009): 381.
} 
spectators. The rough play is attractive to many and it represents the "virile" side of the lacrosse game.

This violence would represent, in the end, an obstacle to its expansion, going even up to its prohibition in the 1900s - the Choctaw append weights at the end of their sticks, in order to hurt their opponents. In 1947, Thomas Vennum related that, during a game, six players were hospitalized during the initial fifteen minutes of the game. ${ }^{73}$

In Ojibwe lacrosse, a player you were pursuing was "hogging" the ball and not passing it, his opponent could yell "bagadon [throw it, get rid of it]." If he still cradled the ball, after the pursuer yelled the command three times, he was permitted to smash the ball carrier's head from behind with his stick. ${ }^{74}$

Everything seems to contribute, at this time, to make the game more violent. Even the ball, in the Great Lakes region, is made from a pine burl, which makes it heavier and harder. A player hit in the head with such a ball is usually knocked out, a fact whose truth can be attested to by Ojibwe Leonard Marksman, who, in 1948, was unconscious for ten minutes as a result of such a shock. ${ }^{75}$ More serious still, the Mohawk Angus Thomas, famous for his powerful shots, was banned from the championship for more than one year, at the end of the 1940s, after having accidentally killed another player.

By the time the Indian game became "more civilized," particularly once Indians began playing white teams and wearing protective equipment, according to the "old-timers" the game had lost its spark and life, and the young players of the day seemed to them to be unable to take the punishment they remembered from their own youth. ${ }^{76}$

This violence can be explained in various ways. First of all, the religious and societal conflicts previously invoked express themselves, from now on, in the stadium. Thus, the violence-sports couple finds itself at the center of forms of projection by identification onto the game and the teams that reinject the social, religious or national oppositions. On the other hand, in a similar way to the beginnings of the American football, the lacrosse rules were, at this time, quite open and left room for total commitment on the part of the players. Afterwards, this "relative" freedom permitted by the regulations will allow the American Indians to express, in a sport able to constitute a substitute for war, some of their fundamental cultural aspects, such as bravery and courage. It is nonetheless difficult to generalize this violence to the entirety of territorial practices, for not all the local evolutions of the game are known. Although American Indian players are well-known-even nowadays - for their rough play, they are generally respectful of the rules within an institutionalized framework. This does not seem to be the case of the Canadians, as emphasized by Donald M. Fisher:

Native dominance of the early contests with white men occasionally led to frustration and violence on the part of the Montreal men. In July 1860, the Montreal Gazette commented on one such accident. "We are sorry to see one of the Montreal players strike one of the Indians with his crosse.

\footnotetext{
${ }^{73}$ Thomas Vennum, Lacrosse Legends of the First Americans (Baltimore: The John Hopkins University Press, 2007), 129.

${ }^{74} \mathrm{Ibid}$.

${ }^{75} \mathrm{Ibid}$

${ }^{76}$ Ibid.,130.
} 
Doubtless the gentleman lost his temper in a rough tumble, but nevertheless it was not the fault of the Indian." 77

Beers also quotes the words of an Indian chief:

We were invited by an Indian chief, at Caughnawaga, early one morning last summer, to witness a game of Lacrosse on the common, among about thirty Indian residents; and after watching a hard-fought game of an hour, the gentle savage turned to us, and said, in broken English: "You can't play Lacrosse like that. You smash heads, cut hands, make blood. We play all day; no hurt, except when drunk." It is very rare that an Indian is injured or injures ever so slightly when playing with his fellow red-skins. ${ }^{78}$

Finally, the symbols related to the game and to the noble American Indian warrior are taken over by the Canadian social elite for the promotional and commercial purposes of a "gentleman's game" that only has, in fact, its appearance. According to Donald M. Fisher:

White proponents often conceptualized the Indian athlete as the "noble savage" first identified by Jean-Jacques Rousseau. This fictional icon of the Enlightenment not only survived well into the twentieth century, as affluent white athletes saw themselves as the symbolic descendants of romanticized Indian warriors of old, but it helped to justify rough, physical, but not excessively violent activity among collegians and schoolboys. ${ }^{79}$

The popularity of the lacrosse among players and spectators is also due to the fact that it represents a transposition of the $19^{\text {th }}$ century North-American space in a sports arena and, for this very fact, a metaphor for conquest, with all the violence it entails. Similar to the American national pastimes (baseball and American football), the codification of lacrosse resumes the symbolic gridding of the agricultural land at the time of colonization and it rests upon the notion of territories to be conquered. ${ }^{80}$ The conditions of the "sportization" of lacrosse echo to those of the European-American society back then, when the space of the solid ground, divided by knowledge and enclosures, by ranks and honors, by traditions and religions, can only make the distance from the American Indian a little more obvious. The traditional forms of organization of the American Indian game areas, are gradually replaced by internal and external demarcations circumscribing the fields or organizing the competition. The brutal confrontations are then to be found in the fluctuating and metaphorical notion of "Border," that falls originally under the category of a political project. This symbolical "territoriality" of sports: "refers to a way of carving and controlling the space that guarantees specificity and permanence, the reproduction of the human groups occupying it. This is its political dimension. It illustrates the intentional nature, the voluntary character of its creation." ${ }^{1} 1$ To a geography of the physical space that must be appropriated by all means, of a continuous and horizontal terrestrial directionality such as the one perceived in its institutional taming by Beers, corresponds a relationship to the world structured by a sacred geography, where the American Indian play space is above all perceived in its vertical, even circular dimension, through its mediating function alongside tutelary spirits or between the two antagonistic powers, the heavenly and the chthonic one.

\footnotetext{
${ }_{77}$ Donald M. Fisher, Lacrosse: A History of the Game (Baltimore: The Johns Hopkins University Press, 2002), 25.

78 William George Beers, Lacrosse. The National Game of Canada, 205.

${ }^{79}$ Ibid., 5.

${ }^{80}$ See John Bale's works on baseball, especially Sports Geography (London-New York: E. \& F. N. Spon, 1989).

81 Guy Di Méo, Géographie sociale et territoire (Paris: Nathan, 1998)
} 
Then, two kinds of incompatible cultural violence express themselves: one that places religiosity at the heart of its act, and the other favoring the symbolism of a territorial and worldwide conquest.

This analysis would not be complete without mentionning the idea of masculinity. Sport takes part in a domination behavior, which explains the confrontations and violence. It will promote patriotism, individualism, achievement, renown and develop the philosophical movement of "Muscular Christianity" that appears in the mid-19th century in England. The national leader Henry Cabot Lodge declares to students from Harvard in 1896 that "The time given to athletic contests and the injuries incurred on the playing field are part of the price which the English-speaking race has paid for being world conquerors." 82 This violence that perpetuates itself allows North-American young men to build and confirm their male identity by means of socialization through sport, a possible alternative to military training. To the total commitment of the American Indians related to the seduction or conciliation of the spirits respond non-statutory aggressive behaviors, having a utilitarian purpose, in order to obtain victory in terms of socio-political or economic imperatives. The game stays, therefore, the field of expression of an instrumentalized violence, whose meaning and interest differ between two cultures that everything opposes to each other.

This problem of violence, even if contained by the ulterior regulations, lasts until nowadays. If the rule of interception "controls" the notion of contact in men-whereas contacts are purely and simply forbidden in women's practice- "the inter-crosse" resumes the educational fundamentals envisioned by Beers. A gradual system of sanctions attempts to control the aggressive behaviors. The technical fouls (minor infringements of the rules of the game) are sanctioned with an exclusion of the guilty player for 30 seconds or with granting a free throw to the other team. More serious fouls involving other players, such as tripping or pushing an opponent, illegally intercepting the ball or committing a brutal act, are punished with an exclusion for 1 to 3 minutes. In 2007, the National Collegiate Athletic Association implemented specific rules in order to grant the security and integrity of the players. Indeed, with the progressive evolution of the shape of the stick towards a deeper pocket, it was more and more difficult to take the ball from one's opponent, and the defenders became more aggressive. This rule change (a shallower pocket) in 2009, permitted to prevent excessive brutality. The permanent search for a more spectacular game remains, in the end, an undeniable factor in increasing its violence.

\section{Conclusion}

Analyzing the violence in the North-American sports games raises a double problem: the very definition of that violence and the trustworthiness and the interpretation of archives.

According to the nature of the sports games, of the time period covered, of the selected analysts, it is possible to mention various forms of violence, thus increasing the range of definitions and associated representations. These types of violence are often associated, even mistaken for the concept of aggressivity and especially for that of "aggression." According to Jacques Pain, "the Anglo-Saxons, for instance, include violence in aggression, whereas in the French language aggression is included in violence." 83 It seems that the players' behaviors fall more under the category of aggressivity, rather than under that of a bloody and physical violence such as the one perceived in martial practices. By their sacred origin, they constitute an appeal to the manifestation of supernatural forces and they remain committed to a form of worship. If the rites of scarification related to the games raise

\footnotetext{
${ }^{82}$ Lew Carlson, "Giant Patagonians and Hairy Ainu: Anthropology Days at the 1904 St. Louis Olympics", Journal of American Culture3 (1989), 20.

83 Jacques Pain, L'école et ses violences (Paris: Economica/Anthropos, 2006).
} 
questions through their violence, the commitment of the participants refers more a form of "aggressiveness" in the sense of overinvestment as required by the ritual in order to please divinities. The children's games that offer them the opportunity of measuring themselves against the others and thus showing their bravery partake more of a form of brutality ("aggressivity"). The halo of definitions pertaining to the concepts of violence and aggressivity hardly dissipates according to the games and the associated rites.

The sports-games maintain, therefore, complex relationships with violence, which can be subject to conflicting analyses, especially since the missiological, anthropological, journalistic or other types of discourse do not always favor the clarifications and understanding of the mores of these civilizations deeply rooted into oral tradition. Quite the contrary, they show the burden of fiction and of an imaginary on the Indianness in the construction of stories about the games. These texts concerning habits and customs unknown in the Old-World match with the rule according to which the image of the other is built starting from a cultural analysis that varies depending on historical circumstances. Culture determines the representation of difference, views of man and the way we write History. The stories collected by the anthropologists in the $19^{\text {th }}$ century already suffer from the dramatic changes brought to the American Indian societies by the arrival of the Europeans since the $16^{\text {th }}$ century. The condescendence of the look directed to the other interferes with the collection of information and invents sometimes a neo-traditionalism such as defined by Eric Hobsbawm. It is still quite difficult, nowadays, to define the real nature of violence in the game, its function and degree. Maybe these historical and anthropological productions have been tempted to rethink the social and ritual activities of the American Indians through the prism of an exacerbated violence, as so many inventions "establishing or legitimizing institutions, status or relations of authority." 44 ? The "invented" or reinterpreted violence, be it in the traditional games or in the warlike practices, is associated to savagery or barbarism (different stages of the social organization in the evolutionary theories) and it legitimizes colonialism. It also legitimizes the prohibition against American Indians practicing their traditional games, in the end of the $19^{\text {th }}$ century, and the obligation of their descendants to devote themselves to the sports practices taught inside the boarding schools.

There is no autonomy for the sphere of violence in the North-American Indian societies. It only acquires meaning in connection with the general network of relations that hold the groups in their grip. Violence is only a particular case of that global system, and it cannot embody by itself the multiplicity of the North-American Indian cultures. Therefore, violence (in all its forms) and games do not constitute two types of coexisting relations, but, rather, two opposed and inseparable aspects of one and the same social process. They are "the continuity specific to the elements of a social whole." 85 The North-American Indian societies have often been reduced to their conflictual relations and to the expression of a certain violence. This violence within sports-games falls under the category of mythicalreligious achievements, of catharsis, of warlike education or of economic interests. It seems quite difficult to see in this revealed other a being whose first, whose exclusive, even, expression of supposed "savagery" is violence. Therefore, this is not a hostile violence, but rather an instrumental one.

The history of sport is very revealing for this ambiguity of analysis. If we can easily find articles on the violence inherent to the original lacrosse game, describing its warlike features and its "sacrificial" victims, there are few traces of the appropriation by the American

${ }^{84}$ Eric Hobsbawm, "Inventing tradition," in The invention of tradition, eds. Eric Hobsbawm \& Terence Ranger (Cambridge: Cambridge University Press, 1983), 9.

${ }^{85}$ Claude Lévi-Strauss, "Guerre et Commerce chez les Indiens de l'Amérique du Sud", Renaissance (New-York, 1943): 138. 
Indians of new sports practices, a very singular appropriation, for it breaks away from the codes of violence. Nevertheless, the American Indians have excelled at these sports which were unknown to their cultures. The example of American football is there to remind us of that.

At the turn of the $20^{\text {th }}$ century, the federal sport invades all the layers of the NorthAmerican society and its school counterpart becomes the representative of the values of a system that encourages competitive spirit, initiative, and success. The initiative of integrating sport into the sports programs is led with such diligence and zeal that the American students benefit of much more substantial infrastructures than those ever developed on the Old Continent. Since the $19^{\text {th }}$ century, the American Indians are faced with a true sports acculturation within the boarding schools. Required to practice sports such as American football in the absence of their games, they rethink the latter according to their own cultural rules. In terms of violent sports practices, football competes with lacrosse. The 1894 Harvard-Yale game, known as the "Hampton Park bloodbath," causes disabling injuries to four players and the encounters are suspended until 1897. Nevertheless, violence only increases, with the death of various players. Nineteen deaths are counted throughout the country in 1905. Theodore Roosevelt denounces since 1893 this violence in the Harper's Magazine and he even threats a little later with prohibiting the game unless radical changes are carried out.

Richard H. Pratt, administrator of the Carlisle Indian School ${ }^{86}$, is suggested by Charles A. Eastman to include American football in the sports education given to American Indians. Pratt's answer echoes the beliefs of the age concerning the hypothetically dangerous and uncontrollable relationship between American Indians and football:

A few years ago, I asked that good friend of the Indian, Gen. R. H. Pratt, why he did not introduce football in his school. "Why," said he, "if I did that, half the press of the country would attack me for developing the original war instincts and savagery of the Indian! The public would be afraid to come to our games!" "Major," I said, "that is exactly why I want you to do it. We will prove that the Indian is a gentleman and a sportsman; he will not complain; he will do nothing unfair or under hand; he will play the game according to the rules and will not swear at least not in public! ${ }^{87}$

Then, the American Indian players take ownership of the game, by developing, in the absence of an aggressive game, a more technical approach, thus choosing the avoidance via, for instance, the twisted pass or the cross or lateral pass, rather than the notion of physical confrontation. For some people, modern football was invented by the Carlisle Indian team. Their play is then unanimously acclaimed. Carlos Montezuma mentionned the propensity to bring the American Indians" success down to their simple athletic quality and to the violent nature of the game, which, "naturally," would suit them:

Instead of the Indian being endowed with qualifications of a savage nature that were particularly adapted to football, and that football is in itself a brutal game is absurd. The contrary has been proved by the record of the football team and is attested by every opponent Carlisle has had. All teams the

\footnotetext{
${ }^{86}$ The Carlisle Indian Industrial School was founded in October 1879 and was designed to assimilate students into the mainstream culture. It was housed in Carlisle, PA at the Carlisle Barracks, now the home of the U.S. Army War College. "Carlisle" became the model for 24 off reservation schools with the purpose of acculturation.

${ }^{87}$ Charles A. Eastman, The Indian To-day: The Past and Future of the First American, (Garden City: Doubleday, 1915), 129.
} 
Indians have contested with have with one accord and without exception pronounced them gentlemen, and have praised their clean, manly playing. ${ }^{88}$

Then a reverse sports' colonization took place, where a defeated people chose innovation over confrontation, by playing on the rules like some trickster from their mythology. The American Indian players have become tricksters in order to preserve their American Indian identity and their social coherence. ${ }^{89}$ By substituting feint or trickery to violence, they have deeply disrupted the game and have dominated, even humiliated the greatest national university teams. But this reverse colonization has its limitations: if they have been deprived of lacrosse, they have only briefly been able to take over football. The Carlisle Indian School was forced to close in 1918. Yet another violence against Indianness.

Translated by Florina Haret

\section{References}

Augustin, Jean-Pierre. "Sports, violences et territoires." Cabiers de géographie du Québec 150 (2009) : 369-384.

Bale, John. Sports Geography. London-New York: E. \& F. N. Spon, 1989.

Bandura, Albert. Social Learning Theory. Englewood Cliffs: Prentice Hall, 1977.

Beauchamp, William M. "Iroquois Games.” Journal of American Folklore35 (1896): 269-277.

Beers, William George. Lacrosse. The National Game of Canada. Montréal: Dawson brothers, 1869.

Over the snow, or, The Montreal carnival. Montréal: W. Drysdale and J. Robinson, 1883.

Belden, George P. Belden, the white chief: or, Twelve years among the wild Indians of the plains. Cincinnati, New York: C. F. Vent, 1870.

Carver, Jonathan. Travels through the Interior Parts of North America. Philadelphia: Key and Simpson, 1796.

Catlin, George. Letters and notes on the manners, customs, and conditions of North American Indians. New York: Dover publications, 1973.

Cushman, Horatio Bardwell. The History of the Choctaw, Chickasaw, and Natchez. Indians. Norman : University of Oklahoma Press, 1999.

Delsahut, Fabrice. «Le rôle du trickster dans les cultures ludomotrices nord-amérindiennes au tournant du XX $\mathrm{XX}^{\mathrm{e}}$ siècle. » STADION40 (2014) : 1-17.

De Smet, R. P. «Quatorzième lettre du P. de Smet. Histoire d'un chef des Assiniboins. » In Précis historique, ed. S. J. Terwecoren. Bruxelles, 1855.

Désveaux, Emmanuel. Quadratura Americana. Genève : Georg Éditeurs, 2001.

Di Méo, Guy. Géographie sociale et territoire. Paris : Nathan, 1998.

Dyk, Walter. Old Mexican, Navaho Indian. Son of Old Man Hat. New York: Harcourt, Brace, 1938.

Carlson, Lew. "Giant Patagonians and Hairy Ainu: Anthropology Days at the 1904 St. Louis Olympics." Journal of American Culture 12 (1989): 19-26.

Eastman, Charles A. The Indian Today: The Past and Future of the First American. Garden City: Doubleday, 1915.

Elias, Norbert. The Civilizing Process. Oxford: Blackwell, 2000.

Fisher, Donald M. Lacrosse: A History of the Game. Baltimore : The Johns Hopkins University Press, 2002.

\footnotetext{
${ }^{88}$ Carlos Montezuma, "Football as an Indian educator," The Red Man (January 1900): 8.

${ }^{89}$ See Fabrice Delsahut, "Le rôle du trickster dans les cultures ludomotrices nord-amérindiennes au tournant du XX"e siècle," STADION (2014):40, 1-17.
} 
Gay, Jean-Christophe. «Le sport, une mise en limites de l'activité physique. » L'espace géographique 4 (1997) : 327-340.

Girard, René. Violence and the Sacred. Baltimore: John Hopkins University Press, 1977.

Grinnell, George B. «Coup and Scalp among the Plains Indians ». American Anthropologist12 (1910): 296-310.

Haile, Berard. "Navaho Games of Chance and Taboo". Primitive Man6 (1933): 35-40.

Hassrick, Royal B. The Sioux: Life and Customs of a Warrior Society. Norman: University of Oklahoma Press, 1964.

Hall, Basil. Travels in North America in the years 1827 and 1828. Edinburgh: Printed for Cadell and Co.; London: Simpkin and Marshall, 1929.

Héritier, Françoise. De la Violence II. Paris : Odile Jacob, 1999.

Hobsbawm, Eric. «Inventing tradition. » In The invention of tradition, eds. Eric Hobsbawm \& Terence Ranger. Cambridge: Cambridge University Press.

Huizinga, Johan. Homo Ludens. Paris: Gallimard, 1995.

J. C. B., Travels in New France by J. C. B. Harrisburg: The Pennsylvania Historical Commission, 1941.

Leighton, Dorothea C. \& Kluckhohn, Clide. Children of the People. Cambridge: Harvard University Press, 1948.

Mauss, Marcel. \& Hubert, Henri. «Essai sur la Nature et la Fonction du Sacrifice ». L'Année sociologique (1899) : 29-138.

Mauss, Marcel \& Beuchat, Henri. «Essai sur les variations saisonnières des sociétés eskimos. Étude de morphologie sociale.» L'Année Sociologique 9 (1906) : 39-132.

Lévi-Strauss, Claude. La Pensée Sauvage. Paris : Plon, 1962.

. "Guerre et Commerce chez les Indiens de l'Amérique du Sud ». Renaissance (1943) : 122-139.

Montezuma, Carlos. «Football as an Indian educator ». The Red Man (January 1900): 8.

Rouland, Norbert. "Les Modes Juridiques de Solution des Conflits chez les Inuits". Etudes Inuit 3 (1979) : 80-102.

Mooney, James. “The Cherokee Ball Play.” The American Anthropologist 2 (1890): 105-132.

Morton, Thomas. "Manners and Customs of the Indians (of New England)." In The Library of Original Sources, ed. Oliver J. Thatcher, 360-377. Milwaukee : University Research Extension Co., 1907.

Perrot, Nicolas. Mémoire sur les maurs, coustumes et relligion des sawvages de l'Amérique septentrionale. Leipzig \& Paris : Librairie A. Franck, 1864.

Petit, Céline «Jouer pour être heureux. Pratiques ludiques et expressions du jeu chez les Inuit de la région d'Iglulik (Arctique oriental canadien), du XIX ${ }^{\mathrm{e}}$ siècle à nos jours. » Thèse de doctorat, Faculté de Théologie et de Sciences Religieuses, Université Laval, Québec \& Université Paris Ouest Nanterre La Défense, 2011.

Pope, John. Tour Through the Northern and Western Territories of the United States of North-America. Richmond: John Dixon, 1792.

Mayer, Francis B. With Pen and Pencil on the Frontier in 1851: The Diary and Sketches of Francke Blackwell Mayer. St. Paul, Minnesota Historical Society, 1932.

Long, John. Voyage and Travels of an Indian Interpreter and Trader, describing the manners and customs of the North American Indians. London: printed for the author, 1791.

Pain, Jacques. L'école et ses violences. Paris : Economica/Anthropos, 2006.

Parlebas, Pierre. Jeux, sports et sociétés. Lexique de praxéologie motrice. Paris : INSEP, 1999.

Pope, John. Tour Through the Northern and Western Territories of the United States of North-America. Richmond: John Dixon, 1792.

Roberts, John M. \& Sutton-Smith, Brian. "Child training and game involvement." Ethnology 1 (1962): 166-185. 
Salter, Michael A. "The Indian Athlete: Exploiting or Exploited?," Paper presented at the $4^{\text {th }}$ Annual Convention of the North American Society of Sport History (Eugene, Oregon, June 17-19, 1976).

. "The effects of acculturation on the game of Lacrosse and on its role as an agent of Indian Survival." Canadian Journal of History of Sport and Physical Education 1 (1972): 28-43. Segalen, Victor. Hommage à Gauguin, l'insurgé des Marquises. Paris : Magellan \& Cie, 2003.

Taladoire, Eric. «Les jeux de balle en Amérique Précolombienne. » La Recherche 272 (1995). Thwaites, Reuben G. The Jesuit Relations And Allied Documents: Travels and Explorations of the Jesuit Missionaries in New France, 1610-1791. Cleveland: The Burrows Brothers, 1898.

Vennum, Thomas Jr. American Indian Lacrosse, Little brother of war. Washington: Smithsonian Institution Press, 1994. 2007. Lacrosse Legends of the First Americans. Baltimore: The John Hopkins University Press,

Weyand, Alexander M. and Milton, Roberts R. The Lacrosse Story. Baltimore: Garamond / Pridemark Press, 1965. 